Yumin Chen*

\title{
Exploring modality in multimodal macrogenre: A social semiotic analysis of EFL pedagogic materials in China
}

\author{
https://doi.org/10.1515/jwl-2021-0016 \\ Received August 9, 2021; accepted November 17, 2021; published online January 3, 2022
}

\begin{abstract}
Given the evolving multimodal features in educational settings, modes other than language further enable the diversity in the realization of meanings and pedagogic goals. This paper explores modality in multimodal pedagogic materials for teaching English as a foreign language in China. Drawing upon the social semiotic approach to modality in visual media, this study provides a comparative analysis of modality markers in different elemental genres that constitute the macrogenre of a teaching unit, with a focus on explaining the underlying reasons for the different choices in terms of coding orientation. It is shown that different degrees of deviation from the accepted coding orientation are employed in different constituent genres of the macrogenre of a given text.
\end{abstract}

Keywords: macrogenre; multimodality; pedagogic materials; social semiotics

\section{Introduction}

This paper explores modality in multimodal pedagogic materials for teaching English as a foreign language in China. Given the evolving multimodal features in educational settings, modes other than language further enable the diversity in the realization of meanings and pedagogic goals. With the extensive research on the multimodal features in pedagogic materials for foreign language teaching in China (Chen 2010a, 2010b; Feng 2021; Zhang 2009, 2010, 2019), the multimodal features of different genres that constitute the macrogenre of a teaching unit require further investigation. Continuing the semiotic analysis of multimodal pedagogic discourse along this line, this study provides a comparative analysis of modality markers in different constituent genres within the same teaching unit as macrogenre by drawing upon the social semiotic approach to modality in visual media (Hodge and Kress 1988; Kress and van Leeuwen 2006, 2021; van Leeuwen 2005).

\footnotetext{
*Corresponding author: Yumin Chen, School of Foreign Languages, Sun Yat-sen University, Guangzhou, China, E-mail: chenym27@mail.sysu.edu.cn
} 
Previous studies on the modality in multimodal pedagogic materials indicate that what counts as real is socially defined and specific to a given communicative context, and how multimodal resources are deployed to convey modality in the pedagogic setting is conditioned by as well as construing the solidarity between textbook editors and different groups of learners (Chen 2010c). However, members of a group or community with the same value by no means have access to merely one style of visual display. The present study aims to investigate how certain modality markers may be adjusted to some extent due to the variations in the topic or focus of the social activity by comparing two constituent genres with different visual features.

\section{Modality in multimodal discourse}

The study of modality began with the "absolute, context-independent truth of assertions" in the philosophy of language before it moved to linguistics (van Leeuwen 2005: 165). Modality concerning the issue of "what counts as real" has warranted scholarly attention of social semioticians in recent years. In social semiotics, modality is "the stance of participants in the semiotic process towards the state and the status of the system of classification of the mimetic plane" (Hodge and Kress 1988: 122). When exploring modality analysts need to examine the semiotic resources available to a speaker/writer in negotiating how true a given representation should be taken.

Drawing upon the social semiotic approach to modality, this study holds that "truth" is the shared truth produced by members of a group or community with the same value, and it is closely related to "affirmation of solidarity" and "assertion of power" (Hodge and Kress 1988). Semiotic processes are social processes, and thus all semiotic phenomena bear signs of modality. In relation to genre studies, some genres (e.g. encyclopedia) are regarded as more factual than others (e.g. fiction). What is regarded to be credible to a certain social group may not be reliable in the eyes of another social group (Hodge and Kress 1988: 121; Kress and van Leeuwen 2006: 171). Whoever controls modality can control which version of reality is treated as the valid version, and the accepted representation of reality will serve as "the basis of judgement and action" (Hodge and Kress 1988: 147). In other words, truth can be constantly challenged and tested in every social or semiotic exchange.

Modality judgements are conveyed through modality markers but interpreted through modality cues. Different genres establish sets of specific modality markers, and an overall modality value acts as the baseline for a specific genre with variations due to viewer/reader differences and other factors (Hodge and Kress 1988: 128, 264). Kress and van Leeuwen (2006: 160-163) provide a detailed analytical framework for analyzing visual modality, in which they have identified eight modality markers, i.e. color saturation, color differentiation, color modulation, 
contextualization, representation, depth, illumination, and brightness. Each of the eight modality markers is regarded as a scale ranging from the maximal articulation to the minimum or absence of articulation. Modality value, nevertheless, does not always increase with the amplification of articulation. In a naturalistic coding orientation, for example, there is a certain point on each of the continuums that represents the highest modality value - namely a "commonsense", "everyday" representation based on the resolution of the standard $35 \mathrm{~mm}$ photographic technology.

As indicated above, the concept of modality deals with the reliability or credibility of messages. In visual communication, photographs are generally taken to be faithful representations of phenomena - a "seeing is believing" motif. The truth value of photographs is based on the dominant, conventional, and most widely accepted perception of reality in contemporary times, which is referred to by Kress and van Leeuwen (2006: 165-166) as naturalistic coding orientation. This reality standard has been defined by modern $35 \mathrm{~mm}$ photographic technology, and any pictorial expression that exceeds or does not meet this standard is thought to be of low modality as far as a naturalistic coding orientation is concerned. Besides the naturalistic coding orientation (Kress and van Leeuwen 2006: 165) there are other contexts in which different kinds of truth are favored. For instance, scientific visuals aim at representing the essence, and thus the diagrams and figures with low articulations in color, perspective, light, and shadow are regarded as images with high modality value, which is often referred to as "abstract coding orientation". There is also technological coding orientation in which the reality principle lies in the "effectiveness" or "usefulness" of a given image as a "blueprint". Still another type of coding orientation is the sensory one, which is primarily used in the contexts where pleasure principle dominates, such as advertising, art, fashion, and interior decoration (Kress and van Leeuwen 2006: 165).

Social relations are "constructed and mediated through semiotic activity" (Hodge and Kress 1988: 161). The social definition of truth is constructed through the affinity and antagonism of social groups, and it reflects the shared value and alignment among members of a given institutional or social group. However, members of a social group with the same value, by no means only have access to one style of visual display. The current research attempts to explore the possible influence of field (Butt 2004; Halliday 1978, 2005; Hasan 1995, 1999; Martin 1992, 1999) on different visual styles with varying modality choices within macrogenre.

Field refers to the social action or institutional practice (Martin 1997: 5). It covers the activity and the domain of experience. The activity is the social and/or semiotic process that the interactants in the context are engaged in. The domain of experience is the field of discourse that they range over - the subject matter, or “topic” (Matthiessen et al. 2010: 107). Recent studies on field include Bowcher's (2014) 
development of its system network based on Hasan $(1999,2009)$ and Butt $(2004,2012)$. This unified system of field focuses on "the nature of the activity in terms of the kind of experience around which it revolves” (Bowcher 2014: 205). Martin (2012, 2019) characterizes field as "a set of activity sequences oriented to some global institutional purpose, alongside the taxonomies of participants involved in these sequences" (Martin 2019: 115). With the common concern with the nature of the activity or activity sequences in the research on field, few studies, nonetheless, have investigated its possible impact on the choice of visual styles in macrogenre.

With reference to the pedagogic materials for teaching English in China, various visual styles are employed in different elemental genres that constitute the macrogenre of a teaching unit. The next section intends to analyze and account for this phenomenon by examining different visual styles that are adopted in two reading materials within the same teaching unit in a senior high EFL textbook commonly used in China.

\section{A comparative analysis of modality in the constituent genres of a multimodal macrogenre}

\subsection{The teaching unit as macrogenre}

The term "genre" has been approached in a great variety of disciplines, while the present discussion focuses on what it means in linguistic sense and draws on the approach to genre that is developed by the "Sydney School". Within SFL, genre is interpreted as a staged, goal-oriented social process (Martin 1984). Genre is the contextual semiosis above the semiotic stratum of register that reflects the "variations in culture” (Martin 1992: 504-507; Martin and Rose 2008: 16).

Genre analysis can be applied both to much longer texts that spread across several pages and to "elemental" genres realized as relatively short texts. Martin (1994) proposes the concept of "macrogenre" to deal with longer texts in which various constituent genres can be identified. Each teaching unit in the EFL textbooks under discussion can also be treated as a macrogenre, in that the entire unit is used to accomplish a specific educational goal and is divided into a number of staged sections. Each of the sections belongs to a specific genre. Take "Unit 2 The Olympic Games” in New Senior English for China Student's Book 2 (People's Education Press et al. 2004: 9-16) for instance. As indicated in the corresponding teacher's resource book New Senior English for China Teacher's Book 2 (People's Education Press et al. 2007: 29), the goal of that teaching unit encompasses four categories, i.e. “topic (Ancient and modern Olympic Games; Olympic spirit), 
vocabulary, function (Talking about interests and hobbies), and grammar (simple future tense)". To achieve this goal, the whole unit consists of eight teaching sections, i.e. Warming Up, Pre-reading, Reading, Comprehending, Learning about Language, Using Language, Summing up, and Learning Tip, and these sections represent different types of genres. For example, Learning Tip (Figure 1 below) is an exposition that explains why the students should be active in pair work or group work, which is intended to provide advice on how to achieve the pedagogic goal of effective communication. The Reading section (Figure 2 below) is a description of modern Olympic Games that takes the form of an interview, while the reading material of Using Language (Figure 3 below) is a narrative concerning two figures in Greek mythology, both of which is related to the topical pedagogic goal.

Martin and his colleagues (Martin 1994; Martin and Rose 2008: 216-223) draw on Halliday's concept of logico-semantic relations to account for the relations between componential genres within a macrogenre. The examination of the relations between different sections within a teaching unit is beyond the scope of the present discussion. The current focus is on the features of the visual styles in comparable teaching sections, e.g. Reading and Using Language within the macrogenre of the unit, with the purpose of explaining the underlying reasons for the different choices of visual styles. The two multimodal texts are comparable because they target the same group of viewers but present different visual styles.

\subsection{Photographs for representing actual scene}

The Reading section considered here (see Figure 2 below) is a description in terms of genre. It describes the modern Olympic Games, with an emphasis placed on the similarities and differences between the ancient and modern Olympics.

\section{LEARNING TIP}

Be active in your pair work or group work. This is important because the more you speak English, the better your English will become. So don't be shy about making mistakes. Make sure that you all get equal turns in talking to the class. When you have finished your talk, ask somebody to tell you how you can improve. In this way you will become more confident in speaking English.

Figure 1: An exposition from textbooks - The Learning Tip section of "The Olympic Games" (Excerpted from New Senior English for China Student's Book 2 [People's Education Press et al. 2004: 16]). Reproduced with permission. 


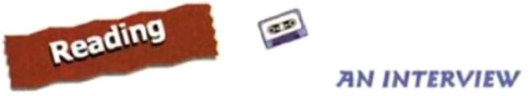

Pausanias, who was a Greek writer about 2,000 years ago, has come on a magical journey on March 18th, 2007 to find out about the present-day Olympic Games. He is now interviewing Li Yan, a volunteer for the 2008 Olympic Games.

My name is Pausanias. I lived in what you call "Ancient Greece" and I used to write about the Olympic Games a long time ago. I've come to your time to find out about the present-day Olympic Games because I know that in 2004 they were held in my homeland. May I ask you some

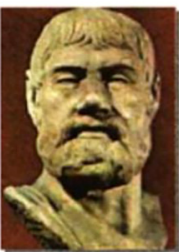
questions about the modern Olympics?

L: Good heavens! Have you really come from so long ago? But of course you can ask any questions you like. What would you like to know?

P: How often do you hold your Games?

L: Every four years. There are two main sets of Games - the Winter and the Summer Olympics, and both are held every four years on a regular basis. The Winter Olympics are usually held two years before the Summer Games. Only athletes who have reached the agreed standard for their event will be admitted as competitors. They may come from anywhere in the world.

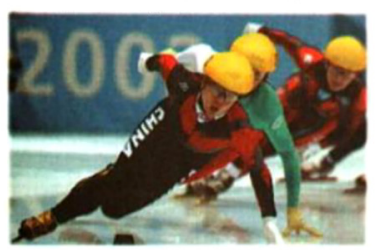

P: Winter Games? How can the runners enjoy competing in winter? And what about the horses?

$\mathrm{L}:$ Oh no! There are no running races or horse riding events. Instead there are competitions like skiing and ice skating which need snow and ice. That's why they're called the Winter Olympics. It's in the Summer Olympics that you have the running races, together with swimming, sailing and all the team sports.

P: I see. Earlier you said that athletes are invited from all over the world. Do you mean the Greek world? Our Greek cities used to compete against each other just for the honour of winning. No other countries could join in, nor could slaves or women!

L: Nowadays any country can take part if their athletes are good enough. There are over 250 sports and each one has its own standard. Women are not only allowed, but play a very important role in gymnastics, athletics, team sports and ...

P: Please wait a minute! All those events, all those countries and even women taking part! Where are all the athletes housed?

L: For each Olympics, a special village is built for them to live in, a main reception building, several stadiums for competitions, and a gymnasium as well.

P: That sounds very expensive. Does anyone want to host the Olympic Games?

L: As a matter of fact, every country wants the opportunity. It's a great responsibility but also a great honour to be chosen. There's as much competition among countries to host the Olympics as to win Olympic medals. The 2008 Olympics will be held in Beijing. China. Did you know that?

P: Oh yes! You must be very proud.

L. Certainly. And after that the 2012 Olympics will be held in London. They have already

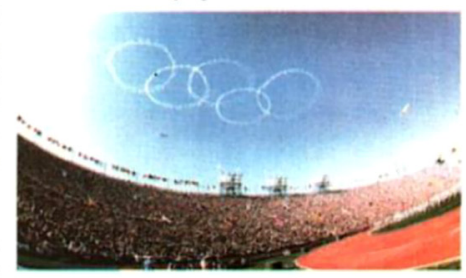
started planning for it. A new village for the athletes and all the stadiums will be built to the east of London. New medals will be designed of course and ...

P: Did you say medals? So even the olive wreath has been replaced! Oh dear! Do you compete for prize money too?

L: No, we don't. It's still all about being able to run faster, jump higher and throw further. That's the motto of the Olympics, you know - "Swifter, Higher and Stronger."

P: Well, that's good news. How interesting! Thank you so much for your time.

Figure 2: A description embedded in an interviews - The Reading section of "The Olympic Games" (Excerpted from New Senior English for China Student's Book 2 [People's Education Press et al. 2004: 9-10]). Reproduced with permission. 


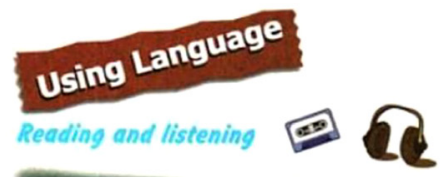

THE STORY OF ATALANTA

Atalanta was a Greek princess. She was very beautiful and could run faster than any man in Greece. But she was not allowed to run and win glory for herself in the Olympic Games. She was so angry that she said to her father that she would not marry anyone who could not run faster than her. Her father said that she must marry, so Atalanta made a bargain with him. She said to him, "These are my rules. When a man says he wants to marry me, I will run against him. If he cannot run as fast as me, he will be killed. No one will be pardoned."

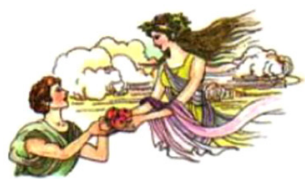

Many kings and princes wanted to marry Atalanta, but when they heard of her rules they knew it was hopeless. So many of them sadly went home, but others stayed to run the race. There was a man called Hippomenes who was amazed when he heard of Atalanta's rules, "Why are these men so foolish?" he thought. "Why will they let themselves be killed because they cannot run as fast as this princess?" However, when he saw Atalanta come out of her house to run, Hippomenes changed his mind. "I will marry Atalanta - or die!" he said.

The race started and although the men ran very fast, Atalanta ran faster. As Hippomenes watched he thought, "How can I run as fast as Atalanta?" He went to ask the Greek Goddess of Love for help. She promised to help him and gave him three golden apples. She said, "Throw an apple in front of Atalanta when she is running past. When she stops to pick it up, you will be able to run past her and win." Hippomenes took the apples and went to the King. He said, "I want to marry Atalanta." The King was sad to see another man die, but Hippomenes said, "I will marry her - or die!" So the race began.

\section{LISTENING TEXT}

\section{THE RACE}

So the next day the race began. Hippomenes was standing waiting and when Atlanta came out she thought, "I do not want this man to die. His death will not be caused by me!" So she said to her father, "Tell him to go away. The race will not be run today." But Hippomenes said, "She has said it: she will be married to the man who runs faster than her. Come on now! Let's run!"

Atlanta ran and Hippomenes ran too. He ran very fast but even so Atlanta ran faster. Soon she was in front of him. Then Hippomenes threw one of the golden apples. It went over her head and fell to the side of Atlanta. She stopped and had to run to get it. Hippomenes ran by. Atlanta looked up and she saw him in front. So she ran faster than the fastest bird. She came near! Then she flew past him and was in front again. Again he threw another apple over her head and to the side. Again she stopped to pick it up.

When she reached Hippomenes the third time, he threw the third apple so far to the side that she had further to go. She saw it and wanted it. So she ran and picked it up. By that time Hippomenes was tired and could not run so fast. He was not so far in front. Atlanta ran fast but the apples were heavy and she could not catch up with him. So Hippomenes won the race and married Atlanta. Thanks to the Goddess they lived happily ever after.

Figure 3: A mythic narrative - The Using Language section of "The Olympic Games" (Excerpted from New Senior English for China Student's Book 2 [People's Education Press et al. 2004: 14] and New Senior English for China Teacher's Book [People's Education Press et al. 2007: 44-45]). Reproduced with permission. 
Description is a kind of factual genre distinct from the report, in the sense that description centers on specific facts about things while the report is concerned with generic facts (Martin and Rose 2008: 5-6). In Figure 2, the description is mainly given by a Chinese girl named Lili, who is interviewed by Pausanias, an ancient Greek scholar who had written about the ancient Olympics and is now assumed to take a magical journey to the present day with the purpose of figuring out the modern Olympic Games. The specific description of the modern and ancient Olympics is as follows:

- Frequency of modern Olympics:

- every four years athletes from all over the world are admitted as competitors

- the Summer and the Winter Olympics [...] both are held every four years

- the Winter Olympics are usually held two years before the Summer Olympics

- Sports events in Winter Olympics:

- skiing and ice skating which need snow and ice

- Participants of ancient Olympics:

- Greek cities used to compete against each other

- no other country could join in

- slaves or women (could not join in)

- Scale of modern Olympics:

- all countries can take part if their athletes reach the standard to be admitted to the games

- there are over 250 sports and each one has its own standard

- women are not only allowed to join in but play a very important role

- a special village is built for the competitors to live in, a stadium for competitions, a very large swimming pool, a gymnasium as well as seats for those who watch the games

- Host of modern Olympics:

- a competition among countries to host the Olympics

- Award of modern Olympics:

- Olympic medals

- still all about being able to run faster, jump higher and throw further

- Award of ancient Olympics:

- the olive wreath

As explained in Section 3.1, the description is embedded in an interview. Pausanias interrupts Lili every time he is shocked by the great changes that have taken place in the modern Olympics, and Lili in return explains what has been replaced and clarifies what remains. Accordingly, a description of the major characteristics of 
modern Olympic Games is presented, as compared with those of the ancient one. There are three images accompanying this description, i.e. a photograph of the sculpture representing Pausanias' head and shoulders, a photograph showing a scene of the opening ceremony of the modern Olympic Games, and a photograph that captures a moment of the speed skating competition in modern Olympics. These three photographs comply with the naturalistic standard that is defined by the $35 \mathrm{~mm}$ photographic technology and represent the scenes in real life that we may see with the naked eye. Although the photograph of Pausanias' sculpture might be seen as a borderline case due to its plain background, its naturalistic way of representing the color, texture, and the play of light and shade convinces us of its naturalistic coding orientation.

It can be inferred that the choice of naturalistic visual style in Figure 2 shows the influence of the field of the discourse, i.e. the topic of the description. Although the interview is an imaginary one, Pausanias was a real writer in Greek history, as is revealed in the written text by the realizations of the noun a Greek writer and the accurate indication of circumstance 2,000 years ago. The corresponding visual image represents the naturalistic sculpture of Pausanias, which is the evidence of his former presence that can be traced in our modern times. Here Pausanias is represented as a historical figure rather than an imaginary comic style character, which helps focus the reader's attention on the factual account of the similarities and differences between the ancient and modern Olympics instead of on the fanciful story about the miraculous journey. Lili is a fictitious character, and yet what she describes about the modern Olympic Games are facts that happen in real life. Therefore, none of the two images that accompany the interview and snapshot of the modern Olympics is about Lili (which would require a comic style). Both photographs represent the real scenes of the modern Olympic Games, which form a cohesion together with the nouns in the verbal text such as the Summer Olympics, the Winter Olympics, and ice skating. This choice of visual style again attaches great importance to the factual information about the modern Olympics that is given in the description rather than the imaginarily timeless interview between Pausanias and Lili.

To summarize, the choice of the naturalistic visual style is in line with the real, factual orientation of the text; while the corresponding images that uphold naturalistic coding orientation, on the other hand, enhance the factual positioning of the discourse that the intended reader is supposed to assume.

\subsection{Drawings for illustrating mythology}

Another constituent genre of the teaching unit is a mythic narrative entitled "The Story of Atlanta”, which tells the story about Atlanta and Hippomenes, two Greek 
mythological figures. The narrative is divided into two parts in the teaching section of Using language. The first part of the story is presented as reading material, while the second part is recorded as listening material. The two parts are combined, and the whole story is represented in Figure 3 below.

In analyzing the narrative structure of "The story of Atlanta”, I draw on Labov and Waletsky's (1997) schema of narrative structure, and Martin and Rose's (2007, 2008) framework for the generic structure of story. Labov and Waletsky's (1997) propose a schema that consists of the stages of Orientation, Complication, Evaluation, Resolution, and Coda to refer to the generalized structure for narratives of personal experience, with Complication and Resolution as obligatory stages while the others optional. In order to overcome the formalist bias that tends to subordinate Evaluation as the boundary between Complication and Resolution, sytemicists have taken Labov and Waletsky's (1997) narrative analysis as the point of departure and carried out a more discourse-oriented approach to the analysis of story types (Martin and Plum 1997; see also Martin and Rose 2008: 49-90). Martin and Rose (2008: 51-52) identify recount, anecdote, exemplum, and observation along with narrative in the story genre family. Narrative is specifically referred to "the generic pattern that resolves a complication" (Martin and Rose 2008: 52), and the evaluation of narrative complications allows variations between affect, judgement, and appreciation, which are often employed to "suspend the action, increasing the narrative tension, and so intensifying the release when tension is resolved" (Martin and Rose 2008: 52). When analyzing the generic structure of story, Martin and Rose (2007) suggest adopting both perspectives of generic stages and phases. Story phases have to do with "a common set of resources" that the story family (i.e. narrative, recount, anecdote, exemplum, and observation) share in "moving sequences forward and engaging readers" (Martin and Rose 2007: 79). Each phase-type has a specific function and may occur in any stage of a story. The narrative structure of "The Story of Atlanta" is analyzed in Table 1 below, with generic stages and phases within each stage specified.

In the beginning, the Orientation (i.e. from Atlanta was a Greek princess to Other men stayed to run the race) presents the heroine Atlanta's identity (i.e. a Greek princess) and the location of the story (i.e. in Greece), her specialty (i.e. very beautiful and could run faster than any man), and the rule that gives rise to a problem (i.e. not allowed to run in the Olympic Games). It is followed by Atlanta's reaction to the rule (i.e. so angry), and another problem for Atlanta (i.e. Her father said she must marry and asked her if she wanted to marry a king or prince). The counterexpectancy signaled by "but" creates tension and leads to another problem for suitors, i.e. Atlanta's insistence that any man who wants to marry her must run faster than her or will be killed, preceding the suitors' different reactions. The Complication (i.e. from There was a man called Hippomenes who was amazed when 
Table 1: The narrative structure of "The Story of Atlanta".

Orientation

Setting

Problem

Reaction

Problem (for Atlanta)

Problem (for suitors)

Reaction

\section{Complication}

Setting

Problem

Solution

Setting

Problem

Reaction

Problem (for Atlanta)

Problem (for

Hippomenes)

Resolution

Solution
Atlanta was a Greek princess. She was very beautiful and could run faster than any man in Greece.

But she was not allowed to run in the Olympic Games.

She was so angry that she said to her father she would not marry anyone who could not run faster than her.

Her father said she must marry and asked her if she wanted to marry a king or prince.

But Atlanta replied, "I will only be married to a man who can run faster than me. When a man says he wants to marry me, I will run against him. If he cannot run as fast as me, he will be killed. No one will be pardoned". Many kings and princes wanted to marry Atlanta but when they heard of her rules, some of them sadly went home. Other men stayed to run the race.

There was a man called Hippomenes who was amazed when he heard of Atlanta's rules. "Why are these men so foolish? Why will they let themselves be killed because they cannot run as fast as this princess?" Then when he saw Atlanta come out of her house to run, Hippomenes changed his mind, "I will marry Atlanta - or die!" he said.

The race started and although the men ran very fast, Atlanta ran faster. As Hippomenes watched, he thought, "How can I run as fast as Atlanta?" He went to ask for help from the Greek Goddess of Love. She promised to help him and gave him three golden apples. She said, "Throw an apple in front of Atlanta when she is running past and she will be relaxed. When she stops to pick it up, you will be able to run on and win".

Hippomenes took the apples and went to the King. He said, "I want to marry Atlanta". The King was sad to see another man die, but Hippomenes said, "I will marry her - or die!"

So the race began. (So the next day the race began.)

Hippomenes was standing waiting and when Atlanta came out she thought, "I do not want this man to die. His death will not be caused by me!"

So she said to her father, "Tell him to go away. The race will not be run today".

But Hippomenes said, "She has said it: she will be married to the man who runs faster than her. Come on now! Let's run!"

Atlanta ran and Hippomenes ran too. He ran very fast but even so Atlanta ran faster. Soon she was in front of him.

Then Hippomenes threw one of the golden apples. It went over her head and fell to the side of Atlanta. She stopped and had to run to get it. Hippomenes ran by. 
Table 1: (continued)

\begin{tabular}{ll}
\hline Problem & Atlanta looked up and she saw him in front. So she ran faster than the \\
fastest bird. She came near! Then she flew past him and was in front \\
again. \\
Again he threw another apple over her head and to the side. Again she \\
stopped to pick it up. When she reached Hippomenes the third time, he \\
threw the third apple so far to the side that she had further to go. She saw \\
it and wanted it. \\
So she ran and picked it up. \\
By that time Hippomenes was tired and could not run so fast. \\
He was not so far in front. \\
Solution & $\begin{array}{l}\text { Atlanta ran fast but the apples were heavy and she could not catch up with } \\
\text { him. So Hippomenes won the race and married Atlanta. }\end{array}$
\end{tabular}

Coda

Comment Thanks to the Goddess they lived happily ever after.

he heard of Atlanta's rules to Soon she was in front of him) describes how Hippomenes marries Atlanta. The hero Hippomenes is introduced with his reflection on how to win the race. It then describes his seeking advice from the Greek Goddess of Love and his marriage proposal. Though Atlanta does not want Hippomenes to die because of losing the race, Hippomenes' insistence creates tension again. The Resolution (i.e. from Then Hippomenes threw one of the golden apples to So Hippomenes won the race and married Atlanta) clarifies Hippomenes' success with the help of the three golden apples given by the Greek Goddess of Love. Every time problem arises and Hippomenes almost loses the race, he throws an apple, which arouses Atlanta's desire, and the tension is resolved. Hippomenes eventually wins the race, and the Coda (i.e. Thanks to the Goddess they lived happily ever after) presents the narrator's comment on the happy ending.

There are two images in "The Story of Atlanta", one depicting Atlanta's negotiation with her father about her marriage and the other illustrating Hippomenes receiving the three golden apples from the Greek Goddess of Love. Both images are color drawings. From the point of view of the naturalistic standard, they are of high modality in terms of color saturation, color differentiation, color modulation, representation, and brightness. For instance, efforts are made to depict the skin color, the textures of people's hair and clothes in a subtle way and as relatively close to what we see with the naked eye. Nevertheless, the images depart from the naturalistic coding orientation in the aspects of illumination, depth, and contextualization. To be specific, there is no play of light and shade in the images, and the simple overlapping leads to the absence of depth. In terms of contextualization, the decoration of the palace and the scenery outside the palace served as the background in the first image are selectively simplified, and what are 
reserved are confined to those architectural features that represent Greek characteristics. As for the background in the second image, the drifting clouds around the lady enhance the indication of her identity as the Goddess.

The targeted viewers of the aforementioned two images are senior secondary students, and naturalistic coding orientation is retained in the representations of certain modality markers as analyzed above. This complies with the general truth criteria in the whole senior secondary EFL textbooks (Chen 2010c). However, deviations from this naturalistic standard are observed in illumination, depth, and contextualization. I will account for this by resorting to the register variable of field. As previously discussed, the topic of the whole discourse is a Greek mythology concerning the Olympic Games. The mythology is supposed to be helpful in students' understanding of the culture and traditions of ancient Greece in which the Olympics is developed, and yet the mythology itself and the characters involved may not be historical events or figures that have ever existed. Moreover, the plot of the mythology is more imaginary than factual. Therefore, it is drawings rather than photographs that are employed to illustrate the remote, ancient story whose historical facticity is hard to nail down. The choice of this fanciful style, on the other hand, induces the putative reader to agree on the imaginary characteristics of the mythic narrative.

From the above analysis and discussion of the multimodal texts within a macrogenre, it could be inferred that field is one of the factors that might exert influence on the choice of visual style. Certain modality markers could be adjusted to some extent due to the topic or focus of the social activity, and the relevant coding orientation may be modified accordingly, thus resulting in the style variations like photographs and drawings that target the same group of viewers.

\section{Conclusion}

It could be inferred from the above analysis and discussion that visual styles with different degrees of deviation from the accepted truth criterion can be employed in different constituent genres of the macrogenre of a given text. The choice of visual style is influenced to some extent by the topic or focus of the social activity, and the visual style on the other hand enhances the putative positioning that the intended reader is supposed to assume. This paper attempts to explore the possible influence of field on the different visual choices within a macrogenre targeting the same group of readers. Pedagogically, it might hopefully provide useful insights for practitioners in identifying and selecting suitable multimodal resources for different constituent genres (description, narration, exposition, etc.).

As Unsworth (2008: 5, 15) points out, collaborative work among practitioners and linguists is necessary to progress the formulation of new multimodal 
pedagogic "grammars" for the iterative processes of assimilation (alternative ways of making meaning) and accommodation (new systems of meaning potential) of new literacies in classroom contexts. With the affordance as well as limitations of the verbal and non-verbal resources made explicit from a social semiotic perspective, we could have one step further towards a comprehensive and critical understanding of the multimodal nature of the present-day pedagogic settings.

Research Funding: This work was supported by the Philosophy and Social Science Planning Project of Guangdong Province (grant number GD19CYY20).

\section{References}

Bowcher, Wendy L. 2014. Issues in developing unified systems for contextual field and mode. Functions of Language 21(2). 176-209.

Butt, David G. 2004. Parameters of context: On establishing the similarities and differences between social processes. Sydney: Centre for Language in Social Life, Macquarie University.

Butt, David G. 2012. Practical sciences, interpersonal meaning, and networks for tenor. Paper presented at the Register and Context Symposium, Macquarie University, 6-8 February.

Chen, Yumin. 2010a. Exploring dialogic engagement with readers in multimodal EFL textbooks in China. Visual Communication 9(4). 485-506.

Chen, Yumin. 2010b. The semiotic construal of attitudinal curriculum goals: Evidence from EFL textbooks in China. Linguistics and Education 21(1). 60-74.

Chen, Yumin. 2010c. Contestable reality: A multi-level view on modality in multimodal pedagogic context. In Ahmar Mahboob \& Naomi Knight (eds.), Appliable linguistics: Reclaiming the place of language in linguistics, 221-233. London: Continuum.

Feng, Dezheng (William). 2021. Focus on forms or focus on meaning: Evaluating the communicativeness of college English textbooks in China. In Zhongshe Lu, Meihua Liu \& Wenxia Zhang (eds.), Teaching and researching Chinese EFL/ESL learners in higher education, 81-100. London: Routledge.

Halliday, Michael Alexander Kirkwood. 1978. Language as social semiotic: The social interpretation of language and meaning. London: Arnold.

Halliday, Michael Alexander Kirkwood. 2005. On matter and meaning: The two realms of human experience. Linguistics and the Human Sciences 1(1). 59-82.

Hasan, Ruqaiya. 1995. The conception of context in text. In Peter H. Fries \& Michael Gregory (eds.), Discourse in society: Systemic functional perspectives (Meaning and choice in language: Studies for Michael Halliday), 183-283. Norwood, NJ: Ablex.

Hasan, Ruqaiya. 1999. Speaking with reference to context. In Mohsen Ghadessy (ed.), Text and context in functional linguistics, 219-328. Amsterdam \& Philadelphia: Benjamins.

Hasan, Ruqaiya. 2009. The place of context in a systemic functional model. In Michael Alexander Kirkwood Halliday \& Jonathan J. Webster (eds.), Continuum companion to systemic functional linguistics, 166-189. London: Continuum.

Hodge, Robert \& Gunther Kress. 1988. Social semiotics. Cambridge: Polity Press.

Kress, Gunther \& Theo van Leeuwen. 2006. Reading images: The grammar of visual design, 2nd edn. London: Routledge. 
Kress, Gunther \& Theo van Leeuwen. 2021. Reading images: The grammar of visual design, 3rd edn. London: Routledge.

Labov, William \& Joshua Waletzky. 1997. Narrative analysis: Oral versions of personal experience. Journal of Narrative and Life History 7(1-4). 3-38.

Martin, James R. 1984. Language, register and genre. In Frances Christie (ed.), Children writing: $A$ reader, 21-29. Geelong: Deakin University Press.

Martin, James R. 1992. English text: System and structure. Amsterdam: Benjamins.

Martin, James R. 1994. Modelling big texts: A systemic functional approach to multi-genericity. Network 21. 29-52.

Martin, James R. 1997. Analysing genre: Functional parameters. In Frances Christie \& James R. Martin (eds.), Genre and institutions: Social processes in the workplace and school, 3-39. London: Cassell \& Co.

Martin, James R. 1999. Modelling context: A crooked path of progress in contextual linguistics. In Mohsen Ghadessy (ed.), Text and context in functional linguistics (Current Issues in Linguistic Theory 169), 25-61. Amsterdam: Benjamins.

Martin, James R. 2012. Register studies: Vol. 4 in the collected works of J. R. Martin. Shanghai: Shanghai Jiao Tong University Press.

Martin, James R. 2019. Revisiting field. In James R. Martin, Yaegan J. Doran \& Karl Maton (eds.), Accessing academic discourse: Systemic functional linguistics and legitimation code theory, 114-176. London: Routledge.

Martin, James R. \& Guenther Plum. 1997. Construing experience: Some story genres. Journal of Narrative and Life History 7(1-4). 299-308.

Martin, James R. \& David Rose. 2007. Interacting with text: The role of dialogue in learning to read and write. Zhongguo Waiyu [Foreign Languages in China] 4(5). 66-80.

Martin, James R. \& David Rose. 2008. Genre relations: Mapping culture. London: Equinox.

Matthiessen, Christian M. I. M., Kazuhiro Teruya \& Marvin Lam. 2010. Key terms in systemic functional linguistics. London: Continuum.

People's Education Press, Curriculum and Teaching Materials Research Institute \& English Curriculum and Teaching Materials Research and Development Center. 2004. New senior English for China student's book 2. Beijing: People's Education Press.

People's Education Press, Curriculum and Teaching Materials Research Institute \& English Curriculum and Teaching Materials Research and Development Center. 2007. New senior English for China teacher's book 2. Beijing: People's Education Press.

Unsworth, Len. 2008. Negotiating new literacies in English teaching. In Len Unsworth (ed.), New literacies and the English curriculum: Multimodal perspectives, 3-19. London: Continuum.

van Leeuwen, Theo. 2005. Introducing social semiotics. London: Routledge.

Zhang, Delu. 2009. Duomotai huayu lilun yu meiti jishu zai waiyu jiaoxue zhong de yingyong [Multimodal discourse theory and its application to foreign language teaching with modern media technology]. Waiyu Jiaoxue [Foreign Language Education] 30(4). 15-20.

Zhang, Delu. 2010. Duomotai waiyu jiaoxue de sheji yu motai diaoyong chutan [Preliminary investigation into the concept of design and the selection of modalities in multimodal foreign language teaching]. Zhongguo Waiyu [Foreign Languages in China] 7(3). 48-53.

Zhang, Delu. 2019. Waiyu zhuanye benkesheng xinxi jishu nengli peiyang moshi yanjiu [A study on the development of English majors' competence in information and digital technology]. Xi'an Waiguoyu Daxue Xuebao [Journal of Xi'an International Studies University] 27(1). 1-6. 